\title{
THE STARS LOOK VERY DIFFERENT TODAY
}

\author{
DAVID STIFTER* \\ Maynooth University
}

\begin{abstract}
This article studies the semantic field of generic words for 'stars', 'constellations', and 'planets' in Early Irish. The Old Irish items discussed are: 1. the hapax ser, 2. rind, 3. the doubtful rét, 4. rétglu, 5. get, and 6. airndrethach. The items are subjected to a close semantic scrutiny, in order to modify the lexicon definitions in cases where this is necessary. In addition, the etymologies of these words are discussed, which results in new or phonologically and morphologically more precise explanations for some of them. In Appendix 1 , a potentially Proto-Celtic poetic formula involving a word for 'star' is reconstructed. Appendix 2 is concerned with Old Irish stíall*, a loan from Latin stella 'star', which only occurs in the name of the feast of the Epiphany.
\end{abstract}

\section{INTRODUCTION}

This article serves the double purpose of bringing the Old Irish semantic field of 'stars' and 'heavenly bodies' together and illuminating more of the prehistory of individual lexical items of this group. Old Irish possesses a large set of words for the lights that populate the space far above the world, many of which have remained etymologically obscure or uncertain. Aside from studies on individual words by various authors, which will be cited in the relevant sections below, only Scherer (1953) and Hamp (1974b), both probably not easily accessible to many scholars, have so far undertaken comprehensive studies of the semantic field from an Indo-European point of view. Scherer's book is, at least from the Celtic perspective, just a collection of the received wisdom of his day and did not mark an advance in knowledge. Hamp's article is, as so often, a tour de force that requires careful reassessment to separate the insightful from the speculative.

\footnotetext{
" This article was written as part of the research project Chronologicon Hibernicum. The research for Chronologicon Hibernicum has received funding from the European Research Council (ERC) under the European Union's Horizon 2020 research and innovation programme (grant agreement No. 647351). My acknowledgements go to Sharon Arbuthnot, Bernhard Bauer, Romanas Bulatovas, Olav Hackstein, Deborah Hayden, Anders Jørgensen, Chantal Kobel, Elliott Lash, Robert Nedoma, Lars Nooij, Fangzhe Qiu, and to the editors of Ériu and the anonymous referee. Outlines of the etymologies developed here were first published in SnaS, an online resource of the Chronologicon Hibernicum project, on 11 to 13 January 2016: see 'star', as SnaS 14/14a/14b, available at: https://www.facebook.com/chronhib/ posts/667874023353102, https://www.facebook.com/chronhib/posts/668071586666679, and https://www.facebook.com/chronhib/posts/668463816627456 (accessed 29 January 2019). The initial spark for this article was the untimely passing - untimely at any time - of David Bowie. This inspired me first to a tribute in the form of an etymology of rétglu, and then to an etymological survey of all Early Irish words for 'star'.
} 
In this article, primarily words for 'stars' and 'stellar constellations' will be examined. While this research will not answer all questions, some etymological relationships will become clearer. It will also become apparent that not everything that twinkles is a star. At the end of the study, the Early Irish sky will look very different indeed: there will be fewer stars up there, but it will also be obvious that speakers of the language distinguished clearly between various types of stellar objects.

The word ser 'star' (dil.ie/37209) is attested only once in Irish. It occurs in an apparently Archaic Old Irish fragment transmitted in the Trefocal-text, in a verse that is ascribed to the sixth-century poet Colmán mac Lénéni:

\section{$\bar{O}$ ba $a^{1}$ mac clēib caindlech ser sirt cach n-ainm ainm Gossa Fer.}

'Since he was a child in the cradle, a shining star, the name of Strength-of-Men [i.e. Fergus] overspread every name.'2

The sequence ser $\|$ sirt was emended by Thurneysen from attested saer sert (LL 5122-3) and ser sit (Book of Uí Maine 143v a 13) in the only two manuscripts that preserve it; the vowel of ser is supported by its rhyme with fer. The identification of its meaning as 'star' rests entirely on the assertion by Thurneysen ('Ser heißt jedenfalls "Stern".'). ${ }^{3}$ It is neither verified by a gloss in the manuscripts which contain the verse, nor included in any of the medieval and early modern glossaries. The semantics of the accompanying adjective caindlech 'candle-like; bright, shining' is the best support in favour of this identification. That ser probably was no longer understood after the Old Irish period is indicated by the spelling saer in LL, as if it were the word for 'freeman'.

Ser ostensibly continues the inherited Indo-European word for 'star' *h $h_{2}$ ster- (cf. NIL 348-54, esp. 352; EDPC 355; Pinault 2007); this is well represented in the British Celtic languages where it provides the normal word for 'stellar body'. The simplex Welsh sêr, sŷr, Middle Cornish ste( $y$ )r, Breton ster express the morphological collective 'stars' (that is, these words have plural agreement and cannot be used after numerals), while a singulative has to be formed for a single object, Welsh seren, Old Cornish steren, Middle Cornish ste $(y) r$, sterran, steryan, Old Breton sterenn, Breton sterenn. ${ }^{4}$

\footnotetext{
${ }^{1}$ The manuscripts have $b i$, which looks like the habitual present tense of the copula. Since $o$ takes a past verbal form when it refers to anterior action, as is the case here, the emendation to $b a$ is warranted.

${ }^{2}$ Text and translation of line 1 after Thurneysen (1933, 199-200, 206); translation of line 2 after Watkins $(1958,89)$; see also Breatnach $(2017,24-5)$.

3 'Ser, at any rate, means "star'.

${ }^{4}$ The precise details of forming singular, plural and collective forms of these words is more complex, but beside the point for present purposes; see, for this, Nurmio (forthcoming).
} 
To this we may also add the name of the Gaulish goddess Sirona/Đirona (= *stīronā), who may have been a stellar divinity (Delamarre 2003,282); as a side note, Sirona does not represent the preform of the British singulative seren either in its root or in its suffix. As Thurneysen and NIL point out, the precise stem formation of Old Irish ser is unknown. The short vowel of ser, which is assured by its rhyme with fer, precludes the direct continuation of the Proto-Indo-European lengthened-grade nom. sg. $* h_{2} s t e r r$, which would have resulted in **sir in Old Irish. Perhaps ser represents a thematised formation *ster-o-; Thurneysen $(1933,200)$ compares the Old Irish $o$-stem ner, gen. neir/nir 'boar', also used as a male personal name, which goes back to Proto-Indo-European $* h_{2}$ ner- 'man, male person' (NIL 332-5) with a similar inflectional type as $* h_{2}$ ster-. The British collective $s(t) e r$ 'stars' is thought to continue a collective or neuter plural formation *sterā. The syntactical context of the single attestation of Old Irish ser does not preclude the possibility that it is either a feminine collective, meaning 'constellation' rather than 'star', in which case it would be formally identical with the British word, or that it is a genitive plural 'the shining one of the stars', in which case the syntagm caindlech ser would mirror that of gossa fer in the next line.

Because of its isolation in Irish, Thurneysen felt obliged to raise the question of whether the word was a loan from Welsh, a rhetorical question that was subsequently reiterated by O'Brien $(1956,171)$ and Vendryes (LEIA S-90), but that was answered by none of the three. In $e D I L$, the noncommittal stance of O'Brien and Vendryes has been awarded a prominent position, in that the first information that the user receives is, albeit qualified by a preceding question mark, that the word is borrowed from Welsh. It seems, though, that Thurneysen dismissed the possibility of a loan for himself and regarded the word as native after all. Given the strong dependency of Irish Christianity in its early centuries on the transfer of external ideas and concepts via British intermediaries, however, and the close personal connections of many churchmen with Wales, the possibility of a learned loan by Colmán mac Lénéni cannot be ruled out. Too little remains of this poet's œuvre to allow an inference about his propensity to use borrowed words. For some further-reaching speculations about an inherited poetic formula involving the etymon ser, see Appendix 1 to this article. On balance, I regard ser as a stray poetic archaism in Old Irish, not as a loan.

\section{RIND}

A common term for heavenly bodies in Early Irish is rind $(\mathrm{u}, \mathrm{n})$, gen. rendo, which $e D I L$ broadly defines as 'constellation, star; planet' (s.v. eDIL 2 rind dil.ie/35319). The editors of the dictionary specify, however, that

the orig[inal] meaning may be that of Lat. signum [i.e. 'constellation'] which it glosses Sg. 69a6, Ml. 2a14; prob[ably] influenced by 1 rind [i.e. 'point, tip, end, extremity'] in its development. In later lang[uage] generally confined to poetry. 
This definition is in essence correct, but it is possible to be more confident and more precise about the original semantics than the dictionary is.

In addition to the instances quoted from the Milan and St Gall glosses, the word naturally occurs several times in the glosses on Bede's De temporum ratione. In all these sources, the word refers almost exclusively to constellations or signs ( $M l$. 2a14, 94d3; Sg. 69a6, 73a11, 73a12, 100a3; Bcr. 18d2, 32a6; Bvi. 2a1.21) or to planets (Sg. 70b07; Bcr. 18b10, 18c4). In $M l$. $145 \mathrm{~d} 3$, however, the context does not indicate any more specific meaning than celestial bodies. The adjectival derivative rindide 5 refers to the zodiac (Bcr. 33d3; Bvi. 2a1.23). If, however, a single star is meant, it is predominantly rétglu that occurs (see Section 4 below). In this sense, the latter is used for the star that guided the magi to Bethlehem (Blathm.45) and for other comets ( $A U$ 1018.7), or, in Modern Irish syntagms such as an réalta thuaidh, to the polar star (see dil.ie/35176). It can also be used figuratively of outstanding persons (Blathm.919, Fél. 3 March).

This fundamental difference in meaning explains the frequent use of the two terms in juxtaposition, for instance renda nime 7 redlanda (Fís Adomnáin $\$ 30$, Leabhar Breac; Windisch 1880,191). This collocation is not simply an instance of the rhetorical figure of hendiadys, but it is the collocation of two polar extremes to indicate the totality of celestial objects, a merism (Watkins 1995, 45), rhetorically similar to pairs such as sun and moon, day and night, or land and sea in English, or, in Old Irish, brat ocus biäd 'clothing and food', which expresses the totality of requirements of the body, protection on the outside and nurture inside. Saltair na Rann abundantly bears out the specific semantics of and the distinction between the two words. ${ }^{6}$ I will cite just a few representative examples. Canto I, 101-4 illustrates the notion that those heavenly bodies that possess a sphere of their own are ranked among the renda:

Ro:suidig secht rinn, réim [cain],

ó firmimint co talmain:

Satuirn, Iöib, Mercúir, Mars

Sol, Uenir, Luna lánmas.

'He established seven heavenly bodies (rinn), a (good) course, from the firmament to the earth: Saturn, Jupiter, Mercury, Mars, the Sun, Venus, the very beautiful Moon.'

\footnotetext{
${ }_{5}$ The unsyncopated form rindide, as against expected $*$ renddae, is due to a special rule whereby syncope is avoided if the adjectival suffix -dae comes after a dental (Wodtko 1995, 236).

6 The quotations from Saltair na Rann are given in normalised spelling, based on David Greene's unprinted edition (available online at: https:/www.dias.ie/celt/celt-publications-2/ celt-saltair-na-rann/; accessed 29 January 2019); all translations are Greene's. Fergus Kelly's Vocabulary to Saltair na Rann (Kelly VocSnR) has been of immense help in identifying all the relevant passages in the text.
} 
Similar ideas are found in $S R 131,202,1801$. The same tally of seven renda is made in Canto CLII, 7921-4, in which at the same time renda and rétglainn are juxtaposed:

\section{Cía lín na rétlann ad·rann \\ mod mall fria rím ós cech dind? \\ Rethait frithrosc íar sét sain, cid cotas.gaib na secht rind?}

'What is the number of the stars (rétlann) which he kindled, it is slow work counting them over every height? They run backwards (?) on a separate path; what holds up the seven stars (rind)?'

Greene should have translated the last word of the stanza as 'heavenly bodies', as he did on other occasions, not as 'stars'. The stanza illustrates that the rétlainn 'stars' are uncountable (also in SR 7292), ${ }^{7}$ whereas the renda 'heavenly bodies' have a definite number, here seven. The noteworthy fact that they are said to be running 'backwards' (frithrosc, there is no reason to put a question mark after this translation) suggests that the poet is thinking of the planets here. ${ }^{8}$ The planets are five in number, so the sun and the moon must be included here in the total count of seven, although they are more commonly treated separately from the renda, as entities in their own right. Rind can also mean a stellar constellation of the zodiac, in which case their number is twelve, for instance in Canto I, 257-60:

\section{At é sein in da sé rind do·rósat Fíadu forfinn ós cach rían rethait fon mbith, riú rethes grían a glanrith.}

'Those are the twelve constellations which the bright Lord has created; they run throughout the world everywhere, the sun runs its pure race against them.'

The zodiacal signs are also meant in $S R 210,212,213,228,232$. In unspecific contexts, rind, which is preponderantly confined to the first four cantos of Saltair na Rann, occurs in SR 123, 274, 510, 706, 707, 778, 845, 865, $2259,4094,7050,7292,7424,7437$. The renda are said to have been established in the Creation ( $S R$ 282). The same is said of the rétglainn ( $S R$ 270, 718; see Appendix 1). Otherwise, rétglu is much rarer in Saltair na Rann.

7 This essential quality of the uncountability of the stars is also the motif of the popular German lullaby Weisst du wieviel Sternlein stehen 'Do you know how many stars are standing (in the sky)'. According to this song, only God can know the answer to this question. It may be surmised that a similar concept lies behind the difference between renda and rétglainn.

${ }^{8}$ See Section 6 for a different term for 'planet'. 
The poem contains two examples of specific stars which do not form part of constellations: the Star of Bethlehem (rétlaind, SR 7537) and the 'four cardinal stars' in the apocryphal etymology of Adam's name (rétglannaib, $S R$ 1054; see Murdoch 1976, 64-66 for the details of the concept). The context of the remaining examples does not help to specify the meaning ( $R R$ 1902, 5274). A remarkable collocation of the two terms is rindglan rétglann ( $S R$ 7292), whereby the compound rindglan ${ }^{9}$ is a preposed adjective to the gen. pl. rétglann. Apart from the semantic tension between the two components of the collocation, from a poetic point of view it effects a sort of complex alliteration on the consonantal frame $R$-(dental)-GL-N.

In the ninth-century Cáin Domnaig, renna is used in contrast to the sun and the moon, but it cannot be determined if it refers to stars in general, as in O'Keeffe's translation below, or to the planets or constellations in particular:

I nDomnach athnuigfither in uli dúl i ndeilb bus áille 7 bus ferr oldás, amail dorónta ina cétoirecc, intan mbete renna nime amail éscai, 7 éscai amail gréin, 7 grían amail sollsi secht samlathi, feib boí isin cétna sollsi do gréin .i. ria n-imarbus Ádaim.

'On Sunday there shall be a renewal of every element in a form fairer and better than at present, as they were made at the first Creation, when the stars of Heaven will be as the moon, and the moon as the sun, and the sun as the light of seven summer days, as it was in the first sun's light even before Adam's sin.' (O’Keeffe 1905, 200-1)

A remarkable instance of rind used for 'stars' in general occurs in Amra Choluim Chille 64 (in normalised spelling, translation after Stokes 1899, 258-9), namely Rímfed rind nime nech in·choí cech dirúais ro. Columb ó Chille cúalammar. 'He would number the stars of heaven who would declare every noble thing that we have heard from Columba.' The meaning of this line is that the number of things that could be said about Colum Cille is as uncountable as the stars in the sky, assigning an attribute to rind that is exactly contrary to their precise countability, to which Saltair na Rann bears testimony. This is explicitly stated in the Middle Irish commentary on the line, where rind is glossed by rétglanna: i. no airmebad rétglanna nime intí no innisfed cach ní rohuais, nó cach ní ñdermar ro chualamar o Cholumb chille 'i.e. he would count the stars of heaven who would relate everything very noble, or everything very vast, that we have heard from Columba' (Stokes 1899, 258-9).

Rind allegedly occurs as the second compound member in the gen. pl. tuaisrenn in the gloss .i. ais innatuaisrenn 'people of the north' (Ml. 94b21;

\footnotetext{
${ }^{9}$ Greene takes it as a compound of 2 rind 'constellation', not of 1 rind 'tip'. If it is understood as the latter, however, the whole phrase ruibni rindglan rétglann could mean 'the multitudes of bright-pointed stars' (pers. comm. Liam Breatnach).
} 
reading as in Thes), where the unattested base túaisrind is taken to refer literally to 'the northern star or constellation' (thus eDIL, dil.ie/42188). This is probably a red herring. Even the most cursory consideration casts doubt on this analysis. The inherited cluster $n d$ is very well preserved in the Milan Glosses ${ }^{10}$ and the vocalism $e$ instead of $i$ is unusual. Lowering in the genitive plural, however, might have been taken over from the $o$-stems. The ending - $\varnothing$ of the genitive plural of neuter $u$-stems, at any rate, is well attested (for this see Stifter, forthcoming).

There is an alternative explanation of tuaisrenn that accounts more straightforwardly for the attested form. The first compound element túais'left, northern', although formally and semantically very close to túaid 'left, north', is probably etymologically unrelated to the latter (LEIA T-165). It is an allomorph of the adverb túas 'up, above', which consists of the directional prefix *t- + *oupsu or rather *oupsi (LIPP 832). From this, an adjectival or adverbial derivative túaisre has been created via the addition of the adjectival suffix *-ro-, further enlarged by the suffix *-iio-, that is *t-oupsi/u-r-iio-. A formal alternative would be to operate with an intermediate collective noun *túasar $<*$ t-oups-ero- or, if it were a very old formation, a formation with the contrastive suffix *-tero-, that is, *t-oups-tero-. The phonological development in the related term úachtar 'upper part', however, which shows loss of the sibilant in the middle cluster of * ouxstero- $<*$ oups-tero-, speaks against the latter reconstruction. ${ }^{11}$

eDIL (dil.ie/42186) gives '(on) the left' as the meaning of túaisre, but one can surely add 'in the north', too. Túaisre is the antonym of desse 'the right side, right hand (and implicitly: south)'. Just as desse stands beside the adjective deisen 'being on the right-hand side' (see Stifter 2015,98-9), ${ }^{12}$ from túaisre a similar formation túaisrenn can be derived. Its - $n n$, contrasting with

\footnotetext{
${ }^{10}$ Instances of assimilation of $n d$ to $n n$ are very rare in Milan. The following data have been extracted from the Milan Glosses Database (Griffith and Stifter 2013).

Word-internally (717 examples), -nd-is always preserved, except for heavy clusters in which special conditions apply, namely angaid (31a14) for andgaid, and the four words indnaide, do indnaig, tindnacol, tindnachtae, which show a slight predilection for simplified - $n n$ - (15 instances; preponderant especially from folio 93 onward) over retained - $n d n$ - (11 instances). Word-finally, there are 557 examples (excluding the article) of retained $n d$ (spelt $<$ nd $>$ and occasionally $<\mathrm{nt}>$ ) against 7 examples of assimilation, namely chlain (23d12) and chláinn (91b17) for claind, cruin (18b4) for cruind, dilgiunn (33c15) for dílgiund, dorosloinn (58a11; emended from MS dorosilc lo in) for doro sloind, lonn (62b22) for lond, rinn (145d3) for rind; thus only $1.2 \%$ of word-final $-n d$ s display assimilation. In 4 of these cases (clain, chláinn, dilgiunn, rinn), the word is the final item of the gloss, that is, the assimilation could be due to utterance-final sandhi. In one case, lonn, the word is followed by a word starting with $d$-, namely dia, which could have 'absorbed' the final $d$ of lond. Cruin could be graphically influenced by the immediately preceding cran (= crann). Dorosloinn is corrupt anyway, so no conclusions can be drawn from it. There are no examples in the Milan Glosses of inverse spelling with $<$ nd $>$, that is, all 323 examples of inherited $-n n$ are written $<n n>$ or $<n>$. In conclusion, the assimilation of $n d$ to $n n$, which becomes so prominent in later Irish, can at best be called incipient in the Milan Glosses. For tuaisrenn this means that there is no compelling reason to regard it as a spelling for **túaisrend.

${ }^{11}$ For the complex developments of clusters with middle $s$ in Celtic in general, see Stifter (2017,1191-2).

${ }_{12}$ One more instance of deisen 'right-hand side' needs to be added to the dossier discussed in Stifter (2015, 98-9). Sg. 217b8 contains the feminine acc. sg. desin, which has been misread as desiu so far (Bauer forthcoming a). The final letter is very clearly an $n$ and not a $u$.
} 
the single - $n$ of deisen, is due to the operation of MacNéill's Law. From túaisrenn another secondary adjective can be derived, namely túaisren $(n)$ dae 'on the left, northern, sinister'. Wodtko $(1995,288)$, who is sceptical of deriving this from *túaisrind, as for instance eDIL (dil.ie/42187) does, points out that the actually attested, synchronically derived secondary adjective from rind is rindide 'zodiac', not **rendae. Túaisren $(n)$ de is only found in the Milan glosses (Ml.39b1, 94b26); its antonym deisnechdae 'southerly' occurs once in Milan (Ml.94b27) and once as desnechdi in the Augustine Enchiridion (gl. 131; Stern 1910,496). It is likely that these terms were created in the learned environment of the glossators in order to render Latin expressions, septemtrionales/sinistra and australes in the case of Milan, externi (for hesterni) in the case of the Enchiridion.

Notwithstanding the foregoing etymological analysis of túaisrenn, there remains nevertheless the possibility that the word never existed in the first place, but that $M l .94 \mathrm{~b} 21$ instead contains a third instance of the adjective túaisren $(n)$ dae. The gloss is found on the margin of the page, which has suffered water damage. What is legible of the gloss reads .i. a is $\mid$ innatu $\mid$ ais rẹn $\mid x x x$ (see Fig. 1). The last line is illegible and consists of what could be two or three letters, indicated here by $x x x$. Its first part could be an $n$, but it would be unusually wide. The character or characters which follow this were represented as two dots by the editors of Thes., but it is not impossible that one or two letters, for instance an $a$, are hiding there under the smudge. The plural tuaisrenna would be a possibility. Since word-internal intervocalic $n d$ is never written $n n$ in Milan (see footnote 10), such a form could not contain the lexeme rind.

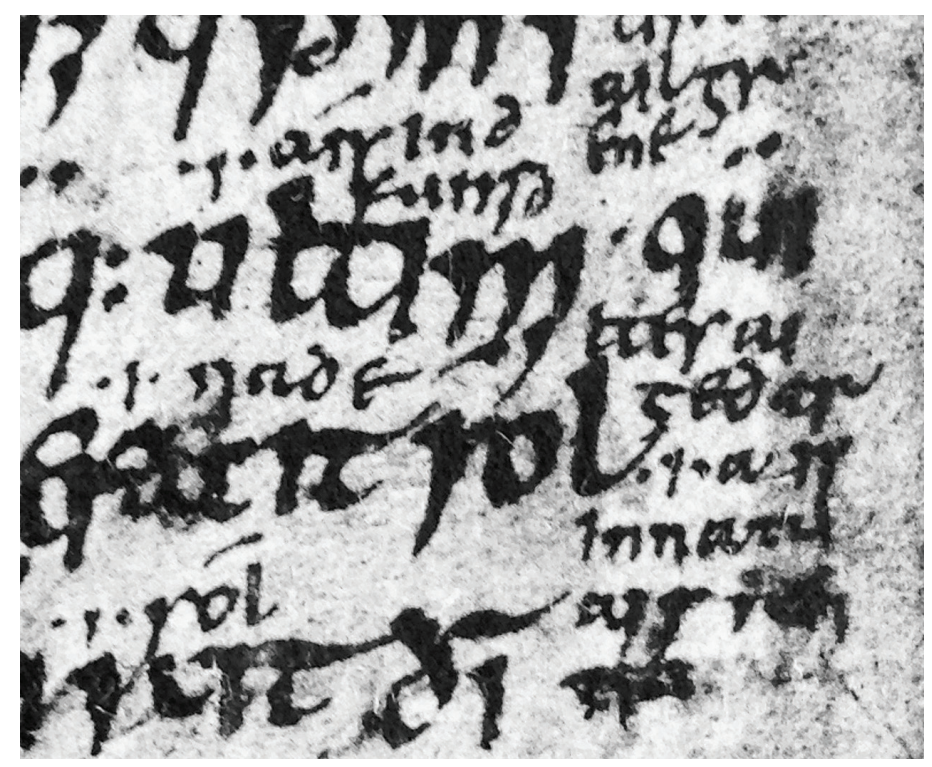

FIG. 1-Gloss on quos nullos tepefacit sol 'whom the sun never warms' (Ml.94b21) 
It is firmly established that 2 rind 'constellation' is a neuter $u$-stem. Nevertheless, there is some variation, and sometimes 'constellation' shows forms that properly belong to $i$-stems, for example dat. pl. rindib, without doubt under influence from 1 rind (i, m) 'point, tip, end, extremity' (both had an identical gen. sg. rendo/a). Based on the synchronic allomorphy of nom. sg. rind, gen. rendo, which presupposes an original $* e$ in the first syllable, *rendu-can therefore be set up mechanically as the immediate preform, although this does not lead to a known Celtic or Indo-European etymology. Perhaps 2 rind is not only influenced by, but related to 1 rind $(\mathrm{i}, \mathrm{m})<*$ rendi-, although the semantic link between the two is not immediately evident, nor is the morphological process by which the one would derive from the other. ${ }^{13}$ 1 rind has a likely cognate in Welsh rhyn in the meaning 'cape, promontory; mountain, hill'. Perhaps rhyn in the meaning 'rigid, stiff, unyielding; turbulent, rough, fierce, threatening, terrible; chilly, etc.', also belongs here. There is nothing that corresponds in the South-West British languages. Old Breton gabl rinn 'pair of compasses' (Angers 477 fol. 12b) is probably a learned loan from the Old Irish compound gabal rind 'id.' (Crb. 18d3), both glossing the same passage in Bede's De temporum ratione. ${ }^{14}$ The noun serves as the basis for the denominal W1 verbs do rinda 'to mark out' ${ }^{15}$ and do foirndea 'to express, signify; to trace, delimitate'.

13 There are other such pairs in Old Irish. One superficially similar pair I can think of is that of Old Irish lind, Welsh llyn, Old Cornish, Old Breton lin, 'pool, lake' and Old Irish lind, Welsh llyn, Middle Cornish lyn, Old Breton pl. linnou 'drink, liquid; brew, ale, intoxicating liquid', where the common semantic denominator is that of a small or large body of liquid. The situation, however, is even more complicated and not directly comparable with that of rind. Several forms of the word for 'ale, liquid' suggest a $u$-stem in Old Irish, cf. gen. lenda, but others look more like an $o$-stem, for example nom. sg. lend, and it is apparently an $o$-stem in Gaulish, cf. acc. pl. linda. 'Lake', on the other hand, is a feminine $\bar{l}$-stem in Old Irish, cf. gen. linde, but perhaps an $o$-stem in Ancient British if the placename Lindum 'Lincoln' can be used as evidence. The neo-British languages do not reveal the original stem class of either word. The etymology is as unclear as that of the two rinds; maybe there is ultimately a connection with the Proto-Indo-European root 2. *leiH- 'to pour' ( $L I V$ 405-6), but the details are far from clear. No comprehensive rule regarding change of stem class in Old Irish word formation can be derived from this case.

A more difficult case is that of rann $(\mathrm{o}, \mathrm{m})$ 'stanza' beside rann $(\overline{\mathrm{a}}, \mathrm{f})$ 'part, share'. The former could be conceived of as 'part' of a poem. An alternative possibility, however, is to regard rann 'stanza' as having been created via a split paradigm from rond/ronn 'chain' (GOI 50; hereafter for convenience's sake, and since no certainty about the original state of affairs can be achieved, only the spelling - $n n$ will be used). If rann is derived from the latter-which is semanticaly attractive - the split must have occurred rather early in Old Irish. To my knowledge, the only attestation of the word in a contemporary Old Irish manuscript is the nom. sg. lethrann in a gloss on the Homilies of Gregory the Great (Paris, BNF Lat. 11884, fol. 10v; possibly ninth century, Fleuriot 1968-71). But the word occurs commonly with the vowel $a$ in Old Irish texts transmitted in later manuscripts, for example acc. sg. rann (Compert Mongáin 11, Immram Brain 293), gen. pl. rann (Immram Brain 2, 15, 142), dat. pl. rannaib : brandaib (Fél. 21 December). The dat. sg. runn and the acc. pl. runnu, attested in Middle Irish manuscripts, could be interpreted both as continuing ronn with regular raising of the vowel, or as later forms of Early Old Irish raunn and raunnu, continuing the stem rann with equally regular $u$-infection. Nevertheless, the split can only have happened under the formal analogy of crann, gen. cruinn 'tree', whose paradigmatic alternation itself is isolated and probably due to analogy (McManus 1992). This question deserves further study.

${ }_{14}$ Cf. Bauer (forthcoming b).

${ }_{15}$ The lack of lowering in do rinda (not $\left.* * d o \cdot r e n d a\right)$ is probably due to influence from the noun rind. Note, at the same time, the lack of raising in do.foirndea (not **do fuirndea). 
No convincing etymology that would satisfy current scholarly standards is known for 2 rind, nor for 1 rind (LEIA R-32). Scherer $(1953,35)$ toys with the idea of connecting 2 rind with the root $* \operatorname{sprend}(h)$ 'to tremble, quiver, jump' (IEW 995-996), in turn an extension of the root* $(s) p(h) e r$ - 'to strew, spray, sprinkle' (IEW 993-4). These roots are set up differently in modern Indo-European studies, however, so that possible links with the Irish word are excluded. The only formally viable root for 2 rind would be * $(s)$ prend'to jump up' ( $L I V$ 583), which is semantically too far removed to fit. Hamp $(1974,1053)$ sets up an arbitrary Celtic root *ren- 'to shine, gleam', which, to my knowledge, finds no support elsewhere. Romanas Bulatovas (pers. comm.) suggests comparing 2 rind 'constellation' with Proto-Slavic *rędz, Lithuanian rindà, Latvian riñda, all 'row, line', < Balto-Slavic *rindo- (Derksen 2008, 436). The root or stem *rind- 'arrangement' (uel sim.) that could underlie the Balto-Slavic and Irish words cannot, however, at present be connected with words and better-established roots in other Indo-European languages. Trying to derive it, for example, from the root $* h_{2} e r$ - 'to join together' (LIV 269-270) or from an extended root * $h_{2}$ reid $d^{h}$ ' 'to put in order' (Kroonen 2013, 402 s.v. ${ }^{*}$ raid $\left.(j) a-\right)$ creates more problems than it helps to solve. Note also that the stressed vowel of pre-Irish *rindu-should not have been subject to lowering (Schrijver 1995, 29).

I want to suggest an alternative etymology. For 1 rind, I tentatively propose a connection with Old Irish aird 'peak, point; point of the compass, direction', which, if cognate with Greek ó $\rho \delta 1 \varsigma$ 'point of an arrow', continues Proto-Indo-European $* h_{2} r d i$ - from an otherwise unattested root $* h_{2}$ erd'point' (Beekes 2010, 127; IEW 63) or 'to sting, prick' (LIV 224 fn. 2). ProtoCeltic *rendi- $<* h_{2} r e-n-d-i$ - or *randi- $<* h_{2} r-n-d-i-$, with similar semantics to Proto-Celtic *ardi-, could arguably be analysed as a variant of this root with what looks like a 'nasal infix'. Nasal infixes are not part of canonical nominal morphology, but they are occasionally transferred from verbal formations into nominal stems, as is the case in all likelihood in Old Irish find 'fair, white' < *uindos. This is usually assigned to the Proto-Indo-European root *ueid- 'to see' (LIV 665-7), with the - $n$ - carried over from the nasalinfix present seen in Old Irish ro-finnadar 'to find out' < *ui-n-d-na-, or Vedic vindáti 'id.' (NIL 722). A more problematic case is Old Irish cuing 'yoke', if it continues something like *kom-iungi- $($ NIL 399, 404) from the root *ieug'to yoke' ( $L I V$ 316). Although this is not a large sample, it does highlight the possibility of encountering displaced nasals in nominal word formation.

Another possible explanation for the apparent ' $n$-infix' is formal influence, probably already in the Proto-Celtic stage, from the semantically proximate Old Irish mind 'sign', Welsh man 'spot, blemish, mark' < Proto-Celtic *mandu- ${ }^{16}$ This is related to Latin mendum, $-a$ 'blemish, fault, error', and may perhaps continue an old collocation *mn- $d$ - or * $m n_{0}-d^{h} h_{1}$ - 'to set one's

${ }^{16}$ In Gaulish, this may be reflected in the onomastic element mandu- (thus d'Arbois de Jubainville, cited in Holder 1891-913, ii 404). Differently Delamarre (2003, 215) who regards mandu- as a word for 'pony'. Old Welsh minn, pl. minnou, the meaning of which appears to be 'crown, circlet; perhaps garland, wreath of flowers' (Nooij 2015, 35-6), is in my view best regarded as a loan from Irish (cf. Falileyev 2000,113-14). 
mind', derived from the Indo-European root *men- 'to think'. In either case, the $u$-stem noun rind 'star sign, constellation' must have been formed beside the $i$-stem noun rind 'point', although the precise morphological process is unclear; maybe it happened again under influence from the $u$-stem mind.

Latin signum offers a close semantic parallel for how a word that originally referred to something 'cut' or 'incised' ('sekHno-, root *sekH- 'to cut off', LIV 524), can become a word for 'mark, sign', and can eventually be used for constellations (De Vaan 2008, 563). The notion that stars or their constellations are marks on the heavenly dome, and constitute signals in the sky to facilitate orientation, has parallels in the Indo-European world (cited after Pinault 2007,274). Vedic provides the phrase pipéśa nákkam stŕbhir (RV I.68.10cd) 'he (god Agni) has marked the firmament with stars', Avestan has asmanəm ... vayhanəm stəhrpaēsayhəm (Yt. 13.2-3) 'the sky ... as a star-spangled garment',

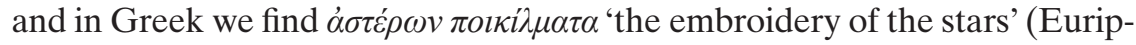
ides, Helena 1096). In all three languages, a word derived from the Indo-European root *peik- 'to cut, engrave, mark' $(L I V 465)$ is used together with $* h_{2}$ ster- 'star' to create a formulaic phrase, for which a case can be made that it belonged to Proto-Indo-European poetic diction. Old Irish could reflect a similar concept if it is assumed that the root *peik-, which has left no trace in the Celtic languages, was replaced by a synonym.

MacQuarrie $(1997,171)$ has suggested that the gloss $W b .20 \mathrm{~d} 6$ be understood as containing an instance of rind as a translation of Greek stigmata, but a close scrutiny of the scanned image of the page leaves no doubt that Stokes and Strachan's reading mind (Thes. i 630) is correct. ${ }^{17}$ As argued above, Old Irish mind possesses the desired meaning 'mark' anyway, so MacQuarrie's fundamental argument about bodily ornamentation remains intact. The meaning 'marks' for $W b .20 \mathrm{~d} 6$ is further corroborated by the preceding gloss $W b .20 \mathrm{~d} 5$ inda errend .i. turmenta flagillorum 'the marks, that is, the pains of the lashings' (translation and interpretation as in Ó Néill 2002,240).

My conclusion is that rind is a word for a 'significant heavenly body', that is, a heavenly body, usually excluding the sun and the moon, that is of practical relevance, be it for measuring time or for orientation and navigation. ${ }^{18}$ Single stars, which had no practical relevance in everyday life, either for navigation or for time-keeping, were referred to as rétglu.

A very rare word for 'star', so rare in fact that 'we are scarcely oppressed' by its attestations, as Eric Hamp $(1973,174)$ remarked, is 2 rét $(\mathrm{u}, \mathrm{n}$ ?). The

${ }_{17}$ The page in question can be accessed online at the Virtuelle Bibliothek Würzburg project website of the Julius-Maximilians-Universität Würzburg: http://vb.uni-wuerzburg.de/ub/ mpthf12/pages/mpthf12/40.html (accessed 29 January 2019).

${ }_{18}$ The notional link between celestial bodies and signs of timekeeping and orientation is also known from the beginning of the Bible, in Genesis 1:14: Fiant luminaria in firmamento caeli, et diuidant diem ac noctem, et sint in signa et tempora, et dies et annos 'Let there be lights made in the firmament of heaven, to divide the day and the night, and let them be for signs, and for seasons, and for days and years.' 
dictionary (dil.ie/35159) records merely two examples, confined to the St Gall glosses on Priscian (Sg. 67b21, 70b6). A third one has been postulated by Greene. I will argue that even this tiny number of attestations can be further reduced.

I start with Greene's example, in Saltair na Rann 2165, where the song of the angels in heaven is described as cainiu rétaib. Greene translates this as 'fairer than stars', but since there is nothing in the wider context (cf. Murdoch 1976,143) that supports this celestial interpretation, it is safer to assume that the poet used the common word 1 rét 'thing' and said something along the lines of 'fairer than (other) things/matter', effectively 'fairest of things'.

In $\mathrm{Sg}$. 70b6, Ennius's poetic use of Hyperionis, the genitive of an epithet of the god Apollo, for the 'sun' is glossed by the Old Irish genitive ind réta $\sin$. Stokes and Strachan (Thes. ii 126.40) translate 'of that star'. This translation, depending as it does on the understanding of modern physics, cannot be correct. In pre-modern astronomy, the sun was no star; it was either an object of its own kind or was grouped together with the planets. Only with the rise of modern astronomy from the sixteenth century onwards was it realised that the sun is just another star. If rét in $S g$. $70 \mathrm{~b} 6$ referred to an object in the sky at all, 'heavenly body' would be a more apt expression. I think, however, that even this may only continue the misunderstanding of the gloss. Incidentally, the very next gloss, $S g$. $70 \mathrm{~b} 7$, refers to a 'star', glossing uesperum (for Hesperium) 'the evening star', that is, Venus. The Old Irish used there is the expected nominative arrind $\sin$ 'that star. ${ }^{19}$ Why did the glossator not use the same word rind in the immediately preceding gloss? LEIA R-22 suggests that 2 rét 'star' is identical with 1 rét $(\mathrm{u}, \mathrm{m})$ 'thing, substance. I want to go further than this and claim that the word in $\mathrm{Sg}$. 70b6 is actually 1 rét 'thing. In the St Gall glosses, the glossator uses 1 rét for 'inanimate objects (opp[ose]d to living creatures) and ... to transl[ate] Lat. res' (dil.ie/35158), for example ainm reto nephchorpdi 'name of an incorporeal thing' (Sg. 187b1) or do rétaib marbdaib 'to dead (= inanimate) things' (Sg. 39a12), contrasted with do persanaib beodaib 'for living persons' ( $S g$. 39a11). I suggest that what the glossator wants to highlight in $S g$. $70 \mathrm{~b} 6$ is that Hyperionis in the verse quoted from Ennius refers metaphorically to the object 'sun', and so is not used in its primary meaning as an epithet for the divine person Apollo. The gloss should rather be translated 'of that object' or, if it is analysed as a copula clause, 'that (is the name) of an object'.

The second alleged occurrence of rét for a heavenly body is in $S g$. 67b21, where Latin arctus 'the Great Bear' is glossed sechtarét, which the editors translate as 'septentrio. The editors interpret sechtarét as sechta rét, that is as a nominal syntagm, consisting of a Late Old Irish form of the numeral substantive sechtae 'a heptad, seven things' and the genitive plural

${ }^{19}$ Thus translated in Thes. ii 126; in view of what was said above, this should better be translated as 'heavenly body', specifically given that Venus is not a star. 
of rét 'star.'20 But there is something wrong in this analysis, as Eric Hamp $(1973,175)$ has rightly argued. With reference to personal communication from David Greene, Hamp rejects the notion that rét can be a genitive in this syntagm. This 'personal communication' by Greene is probably identical to the terse published statement:

In the nature of things, neither of these formations [= substantivised numerals, e.g. a trí 'the three things', and singular neuter numeral abstracts, e.g. tréide] can be used to enumerate a noun at any period of the language (Greene 1992,516).

The examples that $e D I L$ cites for the various numeral abstracts bear out this restriction. ${ }^{21}$ If sechtarét cannot be the collocation 'heptad of stars', it must be a single word.

A suggestively similar form is found twice in the edition of In Cath Catharda, the Middle Irish translation of Lucan's De bello civili. The first example occurs in the sentence ata da faide fodhes itat-sen na faicet acht blogh becc don tisechtarré $[t]$ 'so far are they to the south that they never see more than a small part of the Great Bear' (CCath. 1584); the second one in in lucht aittrebait fo taibh deiscertach in tsleibe sin ni faicet in seachtarré $[t]$ $e$ tre bithu 'those that dwell to the south of that mountain ... never see the seven stars (near the north pole)' (CCath.3813). The manuscripts, however, only have sechtare or sechtaree; the final $t$ is an editorial addition by Stokes. That it was wrongfully inserted is demonstrated by the phrase turcbail cen (f)uiniud uero dont shectarreu 'rising without setting then for the Great Bear' in a martyrology edited by Ó Riain $(2002,151 \$ 9) .22$ This appears to reflect an Old Irish io-stem dat. sg. sechtarreü. From these three attestations it emerges that the word for the Great Bear must have been sechtarré, or rather sechtarreë, a compound of secht 'seven' + 2 ré 'the moon'. In view of sechtarré it seems likely that ré could refer to other celestial bodies as well as the moon. The adjective sechtndelbach 'having seven forms' shows that, in compounds, secht 'seven' as first element could nasalise the second element. Maybe this explains the formation of sechtarré, namely secht $t^{N}+r e ́$ $>$ *sechtrré $>$ *sechtrré, and hence with an anaptyctic vowel sechtarré. This

${ }^{20}$ Thes. ii. $123 \mathrm{fn}$. i has the puzzling footnote '= sechte rét, "heptad of stars", Wb. 26'9', giving the impression that the Würzburg glosses contained another example of this expression. Instead, $W b .26 \mathrm{~d} 9$ contains only an unspecified instance of asechte 'the seven things'.

${ }_{21}$ The only two apparent counter-examples do not involve genitives of the things counted, but they specify the semantic class to which the groups of things belong: cetharda[e] ndillat(a) 'four sets of clothing' (Crith Gablach 198-9), not 'four garments' (MS dillata must be the genitive singular; Binchy unnecessarily emended the gen. pl. díllat in his edition); seda naidbrea= sédae n-aidbreda? 'six things/steps in drawing public attention' (CIH 2164.23), not 'six acts of drawing public attention' (see Binchy 1966, 62 for the meaning of aidbriud).

${ }_{22}$ Pers. comm. Sharon Arbuthnot; see also the eDIL online entry at: https://www.facebook.com/permalink.php?story_fbid=2244160652499511\&id=1559061804342736 (accessed 16 December 2018). Only in the very final phase of correcting this article did I learn that the headword sechtarét 'the Great Bear' of DIL and $e D I L$ ver. 2013 (dil.ie/36805) will be changed to sechtarré in the 2019 version of eDIL. 
word does not seem to have survived into Modern Irish, but Scottish Gaelic appears to continue it under the form seachdaran 'the bear (constellation)' and seachdarran 'Pleiades' (Dwelly 1910, 794), unless this is derived from seachdnar 'seven persons'.

The relationship of sechtarét in the St Gall glosses to sechtarré is unclear to me. The single $r$ could be a scribal slip in the case of a rarely used word, but the final $-t$, which is clearly legible in the manuscript, defies an explanation for the moment. Hamp (1973, 175; 1974b: 1051-2) proposed boldly, as he concedes, to derive sechtarét from a Proto-Indo-European *septem- $(s)$ t(e)r-iones 'seven stars' > Proto-Celtic *sextanterion-, re-interpreted in Latin as septentriones 'the seven threshing oxen'. In Irish, this would have given an intermediate *sechtarenn that subsequently underwent influence from rét 'star', to yield the attested sechtarét. Since, as has been shown above, the sole unequivocal evidence for rét as a heavenly body is in $S g$. 67b21 with reference to the Great Bear, Hamp's argument is circular.

Pedersen ( VKG ii 47) compared rét 'star' with Old Irish ré 'moon' < ProtoCeltic *riio- (or something along those lines), and he accordingly reconstructed rét as *riianto-. Such a preform should, however, have resulted in a form with hiatus in Old Irish, approximately * reät, of which no trace can be found. A faint possibility is $* h_{3}$ reiH- 'to whirl, undulate' (LIV 305-6) if a participal formation $* h_{3}$ riHnto-, transferred into the $u$-stems, is invoked. ${ }^{23}$ One would have to assume an original meaning 'twinkling', but this requires so many ad-hoc assumptions about the development of the vowel that this etymology is best abandoned.

Given the massive doubts about the very existence of such a word, we are justified in asking what sense there is in discussing the etymology of the item separately from that of rét 'thing' in the first place. The strongest evidence for the existence of a simple noun rét 'star' comes from the fact that it seems to form the first element of the compound rétglu, but, as will be seen in Section 4, the precise nature of rét is not illuminated by a detailed analysis of rétglu either. It is not impossible that the compound rétglu employs rét 'thing' simply in a specialised meaning.

The immediate preform for rét 'thing' can only have been Proto-Goidelic *rentu-, which in turn can continue several Proto-Celtic reconstructions, for example * $(\varphi)$ rentu-, $*(\varphi)$ rantu- (cf. LEIA R-22 and Irslinger 2002, 153), none of which has been connected beyond doubt with a known root of Indo-European. Potential candidates exist and have been suggested: $I E W$ 865 sets up a root *rent- 'thing' to accommodate both Old Irish rét 'thing' and Old Indic rátnam 'possession, goods', but the etymology of the latter is regarded as obscure, unless there is a-formally irregular-connection with the root *reh - 'to give', which also underlies Latin rēs 'thing' (EWAia II 428-9, 443; LIV 499). Pace Irslinger $(2002,153)$, it is formally conceivable

${ }^{23}$ It is not clear what *int should have given in Old Irish. The one example adduced by McCone $(1996,55)$ fet 'whistle' < *uinto- <* $h_{2}$ ueh $h_{1}$ to- 'wind' is not conclusive since it could continue *suizdo- 'whistle'. 
that $* r(e) h_{1} n t u$ - would have yielded a suitable preform for rét,$^{24}$ depending on what the outcome of *enttint in Irish is (cf. footnote 23). The morphology of the formation (a $u$-stem built on an $n t$-participle?) is, however, problematic. Irslinger herself suggests an abstract $* h_{1} r(e) m$-tu- 'prop, support' from the root * $h_{1}$ rem- 'to become calm, settle down' (LIV 252-3), which would then have undergone a semantic broadening to 'thing.25 Although phonologically possible, the semantic distance between the root and the noun allows no decision.

When one compares the Proto-Goidelic reconstruction of rét, *rentu-, with that of rind 'constellation', *rendu-, it looks as if the two were only separated by the alternation in the quality of the dental, voiced or voiceless. This is probably just a chance similarity. I am not aware of a similar such alternation elsewhere. Hamp (1974b, 1053), on the other hand, who accepts the reality of rét 'star' and who operates with the idiosyncratic root *ren- 'to shine, gleam', analyses rét<*ren-tu- as an abstract and rind <*ren-du- as an unspecified adjectival formation of that root. This is completely ad hoc.

Ultimately, no final conclusion can be drawn about the etymology of 1 rét 'thing' and, implicitly, the origin of the first element of rétglu. From the discussion above it should have become clear, however, that the word 2 rét 'star' does not exist.

\section{RÉTGLU}

Rétglu, gen. rétglann (n,f) 'star' (dil.ie/35163) is the ordinary Old Irish word for single 'stars' that are not of importance for time-keeping or orientation (see Section 2 above). In the course of time, it encroached upon rind and ultimately replaced it completely. In Middle Irish, the medial cluster was first simplified to rétla, and then became rélta through metathesis. Classical Modern Irish forms are réadla (: céadna), réalda (réaldann : éadrom), réalla (ríréallain : díreóghaidh) and metathesised réalta. It eventually yields Modern Irish réalt, the common word for 'star'. The dental is now voiceless, whereas it must have been voiced in the Old Irish form.

Old Irish rétglu is clearly a compound of the rét mentioned above + a second element - glu. A similar analysis was made by Cormac mac Cuilennáin already in the ninth century: rètglu .i. rèt glè ar a soillsi' 'a bright thing, because of its light', where he equates the morpheme -glu with the similar-looking

${ }^{24}$ Schrijver $(1995,29)$ cites a suggestion by Hilmarsson according to which Tocharian A șont 'path, way' continues *sēntu-<*seh-ntu-; if this reconstruction were correct, it would also offer a suitable explanation for Old Irish sét 'path'. As Olav Hackstein (pers. comm. 9 December 2018) informs me, however, Tocharian A șont could just as well continue the Proto-Indo-European root *sent- 'to go', either via a formation *sēntu- with lengthened grade, or through an ablauting paradigm *sentu- $\sim$ *sontu-, whereby the $e$-grade allomorph supplies the palatalisation of the $s$-, and the $o$-grade the colour of the vowel. Old Irish sét, in turn, can continue the ablaut variants *sentu- or *sntu-.

${ }^{25}$ Irslinger actually refers to the meaning 'setzen, legen' (to put) which was used in the first edition of $L I V$. In the second edition, which has been used as the basis for this article, Martin Kümmel defined the meaning as 'ruhig werden' (to become calm, settle down). 
adjective glé in the Isidorian tradition of etymology. ${ }^{26}$ While Cormac's etymology can of course not be taken literally, an accepted modern etymology has not so far been suggested. Stüber $(1998,117-18)$ includes the word in a list of 'Stems without Etymology'.

By deductive reasoning, however, an etymology can be found for the element -glu that has so far remained as obscure as the rest of the word. Since the word inflects as an $n$-stem, its second element can be dissected into a 'root' part * $g l$ - + suffix *-on-. The 'root' * $g l$ - is reminiscent of various words in Irish and Celtic that refer to colours or to brightness, such as Old Irish gel 'bright', glan 'pure', glas 'green, blue, grey', glúair 'bright', or, indeed, glé 'clear', as noticed by Cormac mac Cuilennáin. A connection with this family of words is semantically attractive for a word for 'star'. The final $-u$ in the nominative, -ann in the genitive, must go back diachronically to two syllables, ${ }^{27}$ since otherwise the ending in the nominative (Proto-Celtic $*-\bar{u}$ ) would have become $-\varnothing$ through regular apocope in late Primitive Irish. Operating with the hypothesis that -glu is a noun meaning 'shiner, glower', the obvious comparandum is with British words for 'coal, charcoal', namely Welsh glo, Old Breton and Middle Breton glou, Modern Breton glaou, Middle Cornish glow, which go back to Proto-Celtic *glāuo-, either from Proto-Indo-European * $g^{h} h_{3}$-uo- or * ghle/oh-uo- (Zair 2010-11, 198-9). The Irish word for 'coal', gúal (o, $\mathrm{m}$ and $\overline{\mathrm{a}}, \mathrm{f}$ ), can also be added to this dossier as a further removed relative. It looks like a reduplicated formation Proto-Celtic *goglo- or *guglo-. The root $* \sqrt{ } g^{h} l e h_{3}{ }^{28}$ is also reflected in the Germanic words Old Saxon glöian, Old High German gluoen 'to burn', Old English glowan 'to glow', Old High German gluot 'glowing coal'. What distinguishes Old Irish - $g l u$ from its thematic-stem British cognates is that another suffix has been added to it, namely *-on-, which had an individualising or agentive force in Celtic (Stüber 1998, 85-168).

The resulting Proto-Celtic reconstruction is nom. *glāun , gen. *glāuonos 'glower, shiner'. If this word were attested as a simple noun in Old Irish, it would probably be *glao, gen. *gloön. The formation and the phonology would be parallel to Old Irish brao, broön, Welsh breuan, Old Cornish brou, Middle Breton brou, breau, Modern Breton breo 'quern, hand-mill' $<$ Proto-Celtic *brāunu, brāuon- < Proto-Indo-European * $g^{u} r a h_{2}-u$-on'heavy thing' (Schrijver 1995, 122-3; Stüber 1998, 94-5). There is in fact a rare word of the shape glau/gló recorded in eDIL (dil.ie/26109), but its meaning seems to be 'ball', cf. also glúán 'little ball' in O'Mulconry's Glossary (OM 679). This is probably a different etymon. Gló- occurs also as a

${ }^{26}$ Early Irish Glossaries Database 1086; the database can be accessed at: http://www.asnc. cam.ac.uk/irishglossaries/concordances.php? main $=9 \& \mathrm{cpFamily}=$ sc \&display $=$ fulltext $\&$ readin $\mathrm{gID}=18086 \# 18086$ (accessed 16 December 2018).

${ }^{27}$ Hamp's (1974b: 1053) bizarre reconstruction *glōn-, of unspecified meaning, which supposedly underlies both Old Irish rétglu and Germanic *tungla 'star', is thus shown to be impossible.

${ }_{28}$ There is some uncertainty about the nature of the initial voiced guttural and about the laryngeal of this root in Proto-Indo-European, neither of which, however, has any relevance for the outcome as *glā- in Celtic. 
first element of compounds, in some of which its meaning is even harder to determine. Lambert (1990) has convincingly argued that gláosináithe/ glósnáithe 'line, rule' is a hybrid loan from Old Breton gloulini 'coal-line, i.e. a plumbline whose thread was covered in coal'. In the Old Irish word, according to Lambert, the first element gláo- was borrowed from Breton glou 'coal', whereas the second element substituted the native snáithe 'thread' for the foreign lini 'line' < Latin linea. eDIL (dil.ie/26157) notes that the first element of gláosináithe also appears as glón-. The - $n$ could be anticipatory to the $n$ of snáithe, especially since the $\dot{s}$ was a weak $/ \mathrm{h} /$ at best, but in view of what was said above one wonders if glón- is actually the inflectional stem of the word gláo 'coal, glower' - and thus not a loan? Be that as it may, *gláo must ultimately have been lost as a simplex and survives only as the second member of a compound in which, restricted to unstressed position, it has been regularly reduced to -glu, -glann in Old Irish.

This etymology has diachronic implications for the morphology of a subclass of animate $n$-stem nouns. The nominative rétglu $<*$-glāun , which is attested in this spelling in contemporary Old Irish sources, demonstrates how the ending of other words, which are only contained in Middle Irish or later sources, would have looked in Old Irish: for instance, the nominative singular of altra, gen. altrann 'fosterfather' < *altrauon- 'nourisher' (Stüber 1998,109 ) must have been *altru in the earlier period. For other words of this type, nominatives in $-o$ are occasionally found in later sources that may be considered as an alternative spelling for the rounded vowel resulting from the sequence *-aūu, for example cano, cana 'whelp' < *kanaū (cf. Middle Welsh ceneu, pl. canawon 'id.', Stüber 1998, 119-20). In the Old Irish of the seventh and early eighth century, the genitive ending would probably have displayed a rounded vowel as well, as witnessed by occasional spellings in later copies. Although not attested for the present word 'star', other words with a comparable structure can be adduced for this orthographic practice, for instance gen. sg. Manonn ( $A U$ 528.1,711.3) 'Ochill Mountains, Dumfries (Scotland)' (cf. eHogan 21357), or the personal name Canonn (AU 621.3, 673.3 , etc.), perhaps 'whelp'. From this, an early Old Irish paradigm Manu, Manonn (later Manann) and Canu, Canonn (later Canann) can be pieced together.

Looking beyond Celtic, Old Icelandic possibly furnishes a formal parallel or even direct cognate for Proto-Celtic *glāuon- 'glower' < Proto-IndoEuropean *ghlh $h_{3}-u$-on- or *ghle/oh $-u$-on-. Alvíssmál st. 16 contains the acc. sg. eygló 'ever-shining' as the word for the 'sun' in the language of the giants. Its nom. eyglóa is also said to be a poetic word for the moon. Nom. -glóa, acc. -gló 'shining, shiner' could form parts of the paradigm of a feminine -on-stem of Old Icelandic (pers. comm. Robert Nedoma), which means that we would also find an $n$-stem extension on *gle/oh$h_{3}-u$ - as the second member of a compound in that language.

Anders Jørgensen (pers. comm. 14 March 2016) suggests that the stem *glāu- might also underlie the Welsh root *low- in lleuad 'moon', lleufer 
'light', etc., if one assumes that the initial $l$ - in leniting contexts had been misanalysed as the lenited counterpart of $l l$, not of the historically correct $\mathrm{gl}$. Such an explanation would solve the problem of the isolated root *low'to shine' which is securely attested only in Welsh without solid etymology.

Another $n$-stem word for 'burner' which only survives as the second element of compounds, namely in compounded personal names, is *aíd, gen. -aidon/-edon < Proto-Celtic *aidon- < Proto-Indo-European *haid ${ }^{h}$-on-, from the Proto-Indo-European root * $\sqrt{ } h_{2}$ eid ${ }^{h}$ - 'to set aflame' ( LIV 259). The root is also found in the glossary term Old Irish áed 'fire', which is used to explain the homophonous $u$-stem personal name, as well as in the Gaulish ethnonym Aedui. The $n$-stem derivative is found in names such as gen. sg. Ogam BIVAIDONAS, BIVODON, in LUGUAEDON in the early inscription in Roman letters from Inchagoill (CIIC 1), or in Old Irish genitives such as Nemaidon, Cinedon, Lugedon, etc. (Stüber 1998, 102).

\section{5. $*_{G E T}$}

A possible further candidate as a word for 'star' must be mentioned here; it is, however, not securely attested before the modern Gaelic languages, and it has undergone considerable semantic change. O'Brien (1956) drew attention to a word used for 'spot on an animal', namely Modern Irish gead, gen. geide "a "blaze" or white star or lozenge, g[e]n[eral]ly. on the forehead of a horse, etc; a grey spot in the human hair; ... a little plot of ground ...' (Dinneen 1927, 522), Scottish Gaelic gead 'small spot of arable land, ... star or spot in a horse's forehead ...' (Dwelly 1910, 481). eDIL (s.v. gead dil. ie/25469) defines the word as 'an atom, point, spot'.

O'Brien, who was also a scholar of Slavic languages, compared gead with Old Church Slavonic gvězdal zvězda, Russian звездá, Polish gwiazda 'star', etc. The equation is beset with difficulties, though. The Slavic words must be related to the Baltic words for 'star' (which O'Brien did not mention), namely Lithuanian žvaigžde (var. žvaižde, žvaizdè), Latvian zvaigzne; Old Prussian swāigstan 'shine, glow' belongs here as well. The considerable formal variation within Baltic, however, does not permit an easy reconstruction even of the Balto-Slavic preform. Depending on whether the $g$ of the Baltic words is regarded as secondary and intrusive, or whether the second $\check{z}$ of Lithuanian is regarded as original or due to assimilation of an earlier $z$, several preforms are possible, such as * $g^{(h)}$ uoisda (Hamp 1974; 1974b, 1053) or * $\hat{g}^{h} u o i \hat{g}^{h}-d^{h} \mathrm{eh}_{1}$ - or $* \hat{g}^{h} u o i d^{h}-d^{h} \mathrm{eh}_{1}$ - (Derksen 2008, 196), the latter perhaps related to the Latvian verb zvaidrit, zviedrìt 'to shimmer, shine'. Whereas the Balto-Slavic words require the $o$-grade of the root, the Proto-Celtic preform of the Irish word must have had the zero-grade, that is, *guizdā or *guigdā or * guiddā. Probably all three preforms would have yielded Old Irish * get, Modern Irish gead. The Proto-Celtic clusters $* z d$ and $* d d$ would have definitely resulted in a voiced dental stop (spelt $-t$ in Old Irish and $-d$ in Modern Irish), and it is conceivable that $* g d$ would have been assimilated to $* d d$ as well. 
Whatever the precise prehistory of this word, it is not possible to say that it ever referred to stars in the sky in Early Irish; it may have been restricted to star-like spots on the skin or the coats of animals. From the meaning 'spot', gead has, as happened with the corresponding English word, also taken on the meaning 'place' in Modern Irish and Scottish Gaelic, especially 'arable land'; the Scottish-Gaelic diminutive geadag can be used for 'flower-bed or garden-bed' (Fraser 1990-2, 211).

\section{AIRNDRETHACH}

Airndrethach (dil.ie/2308) is restricted to two attestations in the Old Irish glosses on the Karlsruhe Augustine (gl. 2d1) and on the Karlsruhe Bede (BCr. 18b12). The first of these is a gloss on the cursus 'paths' that the sidera 'constellations, heavenly bodies' take. Sidera is rendered in Irish by na secht nairndrecha [leg. airndrethcha] 'the seven main heavenly bodies'. The second gloss is on the multiplex motus 'complex movement' of certain heavenly bodies - apparently the planets since it is they that are 'floating in the most peculiar ways', the so-called epicycles - in ancient and medieval astronomy.

eDIL provides no definition of airndrethach of its own, but it quotes the imprecise translation 'constellation' used in Thesaurus Palaeohibernicus. Airndrethach is a compound of are-inde-reth- (VKG ii 600), also found in the past participle airndrisse in $M l .138 \mathrm{~d} 5$ where it glosses the participle in the Latin phrase (terram) erratam uenís fontium '(earth) traversed windingly by water courses'. Accordingly, airndrethach is a 'wandering/erring heavenly body', that is, a planet. It is a loan translation from Greek $\pi \lambda \alpha v \eta^{\prime} \tau$ (via Latin $^{\circ}$ planeta), a nominal formation of the verb $\pi \lambda \alpha v \alpha$ ó $\alpha \alpha$ ' to err around'. The Latin parallel gloss to $B C r$. 18b41, in the Old Breton manuscript Angers Bibl. Mun. 477 11a22c, has indeed planetae in its place (Bernhard Bauer pers. comm.).

The usage in some of the passages quoted in Section 2 above suggests that in native astronomy the planets could be subsumed under rind. The terminological differentiation from other heavenly bodies that is evidenced by airndrethach arose under Latin and Greek influence and appears to have been limited to learned contexts. Indeed, given its absence everywhere else, it may have been a learned formation created in the scriptorium or the scriptoria from which the two Karlsruhe manuscripts originate.

\section{AbBreviations}

$B C r$.

Carlsruhe Bede edited in Whitley Stokes and John Strachan, Thesaurus palaeohibernicus vol. ii (Cambridge 1901-03).

Blathm. James Carney, The poems of Blathmac son of Cú Brettan together with the Irish gospel of Thomas and a poem on the Virgin Mary. Irish Texts Society 47 (London, 1964). 
$B v i$

CIIC R.A.S. Macalister, Corpus Inscriptionum Insularum Celticarum (Dublin 1945; reprinted 1996).

$e D I L$

EDPC Ranko Matasović, Etymological dictionary of Proto-Celtic. Leiden Indo-European Etymological Dictionary Series 7 (Leiden and Boston, 2008).

eHogan Edmund Hogan, Onomasticon Goidelicum locorum et tribuum Hiberniae et Scotiae. An index, with identifications, to the Gaelic names of places and tribes (Dublin, 1910; revised and corrected by Donnchadh Ó Corráin, Dublin 2017). Available at: https://www.dias.ie/celt/ celt-publications-2/onomasticon-goedelicum/.

EWAia M. Mayerhofer, Etymologisches Wörterbuch des Altindoarischen. (Heidelberg, 1996).

Greene SnR David Greene, Saltair na Rann (Dublin, sine anno). Available at: https://www.dias.ie/celt/celt-publications-2/ celt-saltair-na-rann/.

Kelly VocSnR Fergus Kelly, Vocabulary to Saltair na Rann (Dublin, sine anno). Available at: https://www.dias.ie/celt/ celt-publications-2/celt-vocabulary-to-saltair-na-rann/.

LIPP G.E. Dunkel, Lexikon der indogermanischen Partikeln und Pronominalstämme. Band 1. Einleitung, Terminologie, Lautgesetze, Adverbialendungen, Nominalsuffixe, Anhänge und Indices. Band 2: Lexikon (Heidelberg, 2014).

LIV M. Kümmel and H. Rix, Lexikon der indogermanischen Verben. Die Wurzeln und ihre Primärstammbildungen. Zweite, erweiterte und verbesserte Auflage (Wiesbaden, 2001).

NIL Dagmar S. Wodtko, Britta Irslinger, Carolin Schneider, Nomina im Indogermanischen Lexikon (Heidelberg, 2008).

SnaS David Stifter, Sanas na Sengoídilce. Available at: https:// www.facebook.com/chronhib/ (2015-).

\section{REFERENCES}

Bauer, B., forthcoming a: "Who are we? On the usage of "we/us" in the St Gall Priscian glosses', Celtica (submitted).

Bauer, B., forthcoming b: 'The Celtic parallel glosses on Bede's De natura rerum', Peritia (submitted). 
Beekes, R., 2010: Etymological dictionary of Greek. With the assistance of Lucien van Beek. Leiden Indo-European Etymological Dictionary Series 10. Leiden and Boston.

Binchy, D. 1966: 'Bretha Déin Chécht', Ériu 20,1-66.

Breatnach, L., 2017: 'The Trefocal tract: an early Middle Irish text on poetics', in G. Ó Riain (ed.), Dá dTrian Feasa Fiafraighidh. Essays on the Irish grammatical and metrical tradition, 1-65. Dublin.

Carney, J., 1964: The poems of Blathmac son of Cú Brettan together with the Irish gospel of Thomas and a poem on the Virgin Mary. ITS 47. Dublin.

Carney, J., 1965: 'Poems of Blathmac, son of Cú Brettan', in J. Carney (ed.), Early Irish poetry, 45-57. Cork.

Delamarre, X., 2003: Dictionnaire de la langue gauloise. Une approche linguistique du vieux-celtique continental. Paris.

Derksen, R., 2008: Etymological dictionary of the Slavic inherited lexicon. Leiden Indo-European Etymological Dictionary Series 4. Leiden and Boston.

De Vaan, M., 2008: Etymological dictionary of Latin and the other Italic languages. Leiden Indo-European Etymological Dictionary Series 7. Leiden and Boston.

Falileyev, A., 2000: Etymological glossary of Old Welsh. Buchreihe der ZCP 18. Tübingen.

Fleuriot, L., 1968-71: 'Notes de philologie celtique. V. Une phrase en vieilirlandais dans un manuscrit de la Bibliothèque Nationale', EC 12, 567-9.

Fraser, I.A., 1990-2: 'The agricultural element in Gaelic place-names', Transactions of the Gaelic Society of Inverness 57, 203-23.

Greene, D. 1992. 'Celtic', in J. Gvozdanović (ed.), Indo-European numerals. Trends in Linguistics. Studies and Monographs 57. Berlin and New York.

Griffith, A. and Stifter, D., 2013: A dictionary of the Old-Irish glosses in the Milan Codex Ambrosianus C 301 inf; available online at: https://www.univie.ac.at/indogermanistik/milan_glosses/.

Hamp, E.P., 1973: 'Varia I. 7. sechtarét Sg. 67b21', Ériu 24, 174-5.

Hamp, E.P., 1974: 'Varia 7. Mod. Ir. gead and Slav. zvězda', Ériu 25, 279.

Hamp, E.P., 1974b: 'The principal (?) Indo-European constellations', in L. Heilmann (ed.), Proceedings of the eleventh international congress of linguists. Bologna-Florence, Aug. 28-Sept. 2, 1972, 1047-55. Bologna.

Holder, A., 1891-1913: Alt-Celtischer Sprachschatz. 3 Bde. Leipzig.

Irslinger, B., 2010: Abstrakta mit Dentalsuffixen im Altirischen. Heidelberg.

Kroonen, G., 2013: Etymological dictionary of Proto-Germanic. Leiden Indo-European Etymological Dictionary Series 11. Leiden and Boston.

Lambert, P.-Y., 1990: 'Old Irish gláosináthe 'linea, norma', Celtica 21, 234-9.

MacQuarrie, Ch.W., 1997: 'Insular Celtic tattooing: history, myth, and metaphor', EC 33, 159-89.

Markey, T., 2011: 'Ingvaeonic *ster(i)r- 'star' and astral priests', North-West European Language Evolution 39, 85-113. 
McCone, K., 1996: Towards a relative chronology of ancient and medieval Celtic sound change. Maynooth Studies in Celtic Linguistics 1. Maynooth.

McManus, D., 1992: 'Varia III. On the vocalism of Old Irish crann', Ériu 43, 205-6.

Murdoch, B., 1976: The Irish Adam and Eve story from Saltair na Rann. Vol. ii: Commentary. Dublin.

Nooij, L.B. 2015: The Old Welsh glosses on Martianus Capella reconsidered: an edition, commentary and analysis. Unpublished MA thesis. University of Utrecht. Available at: https://dspace.library.uu.nl/handle/1874/320609.

Nurmio, S., forthcoming: Grammatical number in Welsh: diachrony and typology. Monograph Series of the Philological Society. London.

O'Brien, M.A., 1956: 'Etymologies and notes, no. 5. Mod. Ir. gead; Slav. zvězda', Celtica 3, 170-1.

O’Keeffe, J.G., 1905: 'Cáin Domnaig', Ériu 2, 189-214.

Ó Néill, P.P., 2002: 'The Old-Irish glosses of the prima manus in Würzburg, m.p.th.f.12: text and context reconsidered', in M. Richter and J.-M. Picard (eds.), Ogma. Essays in Celtic studies in honour of Próinséas Ní Chatháin, 230-42. Dublin.

Ó Riain, P. (ed.), 2002: Four Irish martyrologies. Drummond, Turin, Cashel, York. Henry Bradshaw Society 115. London.

Pinault, G.-J., 2007: 'A star is born. A “new” PIE *-ter- suffix', in A.J. Nussbaum (ed.), Verba Docenti. Studies in historical and Indo-European linguistics presented to Jay H. Jasanoff, 273-9. Ann Arbor, NY.

Scherer, A., 1953: Gestirnnamen bei den indogermanischen Völkern. Heidelberg.

Schrijver, P., 1995: Studies in British Celtic historical phonology. Leiden Studies in Indo-European 5. Amsterdam and Atlanta.

Stern, L. Ch., 1910: 'Altirische Glossen zu dem Trierer Enchiridion Augustins in der königlichen Bibliothek zu Berlin', ZCP 7, 475-97.

Stifter, D., 2015: 'The language of the poems of Blathmac', in P. Ó Riain (ed.), The poems of Blathmac son of Cú Brettan: reassessments. ITS Subsidiary Series 27, 47-103. London.

Stifter, D., 2017: '68. The phonology of Celtic', in: J.S. Klein, B. Joseph, M. Fritz (eds), Handbook of comparative and historical Indo-European linguistics. An international handbook. Handbücher zur Sprach- und Kommunikationswissenschaft 41/2,1188-202. Berlin and New York.

Stifter, D., forthcoming 2019: 'An apple a day..., Indogermanische Forschungen 124.

Stokes, W. (ed.), 1899: 'The Bodleian Amra Choluimb chille', RC 20, 31-55, 132-83, 248-89, 400-37.

Stüber, K., 1998: The historical morphology of n-stems in Celtic. Maynooth Studies in Celtic Linguistics 3. Maynooth.

Thurneysen, R., 1933: 'Colmān mac Lēnēni und Senchān Torpēist', ZCP 19, 193-209. 
Watkins, C., 1958: 'Old-Irish sernaid and related forms', Ériu 18, 85-101.

Watkins, C., 1995: How to kill a dragon. Aspects of Indo-European poetics. Oxford.

Windisch, E., 1880. Irische Texte mit Wörterbuch, vol. 1. Lepizig.

Wodtko, D., 1995. Sekundäradkjektive in den altirischen Glossen. Untersuchungen zur präfixalen und suffixalen Wortbildung. Innsbrucker Beiträge zur Sprachwissenschaft 81. Innsbruck.

Zair, N., 2010-11. 'British *-āu- and *-āg-, and the Celtic words for "sun", Die Sprache 49, 194-216. 


\section{APPENDIX I}

In connection with the inherited Celtic word for 'star', *ster-, I want to draw attention to a possibly Proto-Celtic (or even earlier) poetic formula that is only discernible indirectly through phrasal reconstruction. While historical linguistics is mostly concerned with the reconstruction of single words or forms, by the same methods, if we dare, collocations, idioms and formulae can be regained, as Watkins (1995) has masterfully demonstrated. In Blathmac's Poems 11 767-8 (Carney 1964, 64-5), ${ }^{1}$ the poet says of Christ who, in this passage, takes on the appearance of the God of Genesis himself:

\section{is a lám ro:sert indib in fidchill do chaínrindib ${ }^{2}$}

'it is his hand that has strewn (arranged) in them (= the heavens) the gaming-board of beautiful stars'.

If this couplet is stripped of its poetical add-ons and embellishments (such as the wonderful image of the starry sky as a fidchell board, cf. dil. ie/22014), we are left with the abstract formula X STREWS/-ED STARS (in HEAVEN), or in Old Irish sernaid/ro sert renda ( $i$ nnimib). A reflex of this formula occurs several times in Saltair na Rann as well. In the account of the creation of the world, Canto I, 269-70, the poet says:

\section{Rí ro·srethaig sróenaib slamm, do rethaib róenaib rétlann.}

Greene translates, emending the accusatives sróena and róena for the difficult datives sróenaib and róenaib:

'The king arranged ranks of flames (?), the rows of the stars in courses.'

Sernaid has been replaced by the secondary verb srethaigid, derived from the verbal noun sreth, and rétglu has replaced the inherited word for 'star'. The same collocation, this time with the verbal noun sreth, is used by the poet later, in the phrase srethaib ilretha rétlann 'with ranges of stars of many courses' (SR 718).

Parallels to this metaphor, albeit without cognate lexemes, occur in Roman poetry, where, tellingly, signa 'signs, constellations' is used, not stellae 'stars'. Lucretius says in 5,694-5 ... loca caeli omnia dispositis signis ornata... '... all

${ }^{1}$ A provisional revised edition of this stanza has been published at: https://twitter.com/ ChronHib/status/884652986592571392; translations are available at: https://witter.com/ChronHib/status/884653428403838977 and https://twitter.com/ChronHib/status/884653743010189312 (accessed 29 January 2019).

${ }^{2}$ For the purpose of rhyme, the poet uses the dat. pl. rindib, which properly belongs to the $i$-stem 1 rind 'tip, point', instead of the correct $u$-stem dat. pl. rendaib. 
celestial places, adorned with signs arranged ..... And Horace says in Satires 1, 5, 9-10 iam nox ... caelo diffundere signa parabat 'night has already begun to ... sprinkle the heavens with signs'.

I do not claim that the Irish phrases depend on these Latin poets, especially since, as will be argued below, the phrase may have been created within Celtic itself, with native linguistic means. The idea of the stars being randomly scattered in the sky can easily have arisen independently. Bearing in mind what was said in Section 2 of this paper about the meaning of rind, the image understood by the poet is not one of the creator scattering stars across the firmament in a random fashion, but rather arranging meaningful signs and constellations on the night sky that are significant and therefore helpful for mankind.

Since rind is a specifically Irish innovation for the inherited word for 'star', by way of backwards substitution, the phrase sernaid/ro.sert renda ( $i$ nnimib) could theoretically be projected back into Proto-Celtic as *sternati/ stìrt sterās (eni nemisi). Although etymologically unrelated, the verb *sternati/stîrt (from the Proto-Indo-European root *sterh - 'to strew, spread out', LIV 599) and the object *sterās (from Proto-Indo-European $* h_{2}$ ster- 'star') would create the impression of a figura etymologica in Celtic, but the similarity would be just coincidence. In Proto-Indo-European, no etymological connection existed between the roots or stems involved, although the frame of consonants would still have been similar.

This reconstruction of a poetic formula is, I think, more than idle speculation. Intriguingly, the sole attestation of ser in Old Irish (see Section 1 above) is immediately followed by, and forms an intentional alliterative pair with, sirt, ostensibly the preterite of sernaid. They do not form a pair of verb + object, as in the postulated formula, but ser is applied as a poetic metaphor to the king Fergus Tuili mac Feradaig, king of Aui Líatháin, who is the topic of the couplet and therefore virtually the subject of sirt. The verb 'strewed' (translated by Watkins $(1958,89)$ as 'overspread') seems to be used in the transferred sense 'threw to the ground, defeated, surpassed' in this line. The poet evidently took a creative approach to the formula.

As for the comparison of the starry sky to a fidchell board, the Vikingage gaming board found in Ballinderry (Westmeath), now at the National Museum of Ireland, provides a vivid illustration of what the poet may have had in mind. It has holes for the pegs bored into it; held against a light, it creates the impression of a star-sprinkled firmament as James Carney pointed out in a radio broadcast $(1965,49,52)$. Note also the parallel with the board of the East-Asian boardgame go. In its classical lay-out, it consists of $19 \times 19$ lines that result in 361 intersections, almost corresponding to the number of days in a solar year. During the game, white and black stones are placed on the intersections. Celestial vocabulary is used for the most prominent positions on the board. A number of special positions are called hoshi 'star points', and the centremost intersection is tengen 'centre of heaven'. A cosmogonic allegory thus arises from the mundane game. 


\section{APPENDIX 2}

The final word of this survey is recorded only for the sake of completeness, even though it does not refer to a celestial body in Irish. Latin stêlla 'star' was borrowed into Irish as stíall*, which occurs exclusively in the gen. sg. stéille $(\overline{\mathrm{a}}, \mathrm{f})$ or stéill (o) in the expression Notlaic Stéille 'Epiphany, Little Christmas, Twelfth Night'. The corresponding Welsh Ystwyll means 'Epiphany' Because of the lack of an attested nominative, and to distinguish it from stíall (ā, f) 'strip, panel, slat, zone, border', eDIL (dil.ie/38929) records it under the headword stéill(e). It may also underlie the epithet Stíallán* in the entry Colman Stellaen obiit 'Colmán of Stíallán died' in AU 624. This is taken as a placename in eHogan 25198, where it is tentatively identified with the townland of Steelaun (parish Templemurry, barony Tirawley) in Co. Mayo, whose name (Old Irish Stíallán*) probably refers to a 'small strip of land.' ${ }^{1}$ Alternatively, Stellaen (with an archaic spelling of $e$ in the first syllable, and a later, hypercorrect spelling of ae for ái) could refer to the feast day in the name of a cleric. 